\title{
Luer Valve Device
}

National Cancer Institute

\section{Source}

National Cancer Institute. Luer Valve Device. NCI Thesaurus. Code C50260.

A valve that incorporates a Luer fitting. 